ACTA AGROBOTANICA

Vol. 62 (2): 179-185

2009

\title{
COMPARISON OF WINTER HARDINESS AND GROWTH OF Actinidia arguta and $A$. kolomikta CULTIVARS GROWN IN CENTRAL POLAND
}

\author{
Adam Marosz \\ Research Institute of Pomology and Floriculture, \\ Department of Ornamental Nursery Plant Production \\ Pomologiczna 18, 96-100 Skierniewice, Poland \\ e-mail: adam.marosz@insad.pl
}

Received: 1.06 .2009

Abstract

A field experiment with Actinidia arguta and A. kolomikta cultivars purchased from a commercial nursery was conducted in Skierniewice, central Poland. Both Actinidia arguta and A. kolomikta cultivars were planted in June 2005 at a spacing of $3 \times 2.2 \mathrm{~m}$. The aim of the study was to investigate the influence of climate conditions on the growth of eight cultivars of small kiwi fruit and to evaluate their usefulness for orchard culture in central Poland. After three years of growth in different climate conditions, including one of the coldest winters (2005/06) during the last years, and also severe late spring frosts (2007), some conclusion can be drawn. Two cultivars of Actinidia kolomikta have shown quite good resistance to winter and spring frosts, but the growth rate of these plants was rather slow. All the cultivars of Actinidia arguta were damaged by frost during the 2005/06 winter due to the snow-cover level, which was rather thick $(24 \mathrm{~cm})$. One year later all new shoots and leaves of Actinidia arguta cultivars were damaged completely by late spring frosts, which deleted flowering and fruit setting for at least one year. After three years of growth observations, the growth rate of small kiwi cultivars can be divided into three groups: fast growing with 'Jumbo' and 'Genewa'; moderate growing with 'Issai', 'Ken's Red' and 'Weiki' - male and female, and slow growing with A. kolomikta cultivars Dr Szymanowski and Sientiabrskaja.

Key words: actinidia plants, frost hardiness, kiwi fruits, ornamental climbers

\section{INTRODUCTION}

In northern areas, low temperature is the major environmental factor limiting productivity and geographical distribution of horticultural plants. Low temperature decreases biosynthetic activity of plants, disturbs the normal function of their physiological processes and may result in permanent injuries that finally bring about death. Cold hardiness, defined as the ability of plants to withstand sub-freezing temperatures without sustaining significant damage, is an important criterion for evaluation of the cultivation potential of a species or cultivar, and for breeding or selection work (L i n d e n, 2002).

In Poland cultivars of Actinidia arguta and A. kolomikta are fast growing climbers propagated by specialty nurseries and offered on the market as ornamental plants. Sometimes, they are also cultivated for edible fruits, although there are no existing orchards in Poland yet. Fruits of that species are called smallkiwi instead of fuzzy-skin kiwi fruit being sold on the market. Common kiwi fruit with world production of over 53000 ha is represented mostly by A. deliciosa 'Hayward' (X i a o, 1999), but this species is unusable for fruit culture in Poland. Looking for new plants that can be grown commercially and that are valuable for human health is an important task for horticultural science.

Small kiwi fruit vines are little known in Poland and only planted in home gardens. However, there is a real possibility for orchard planting in colder climate zone ( $\mathrm{R} \mathrm{e} \mathrm{i} \mathrm{c} \mathrm{h,} \mathrm{2004).} \mathrm{In} \mathrm{this} \mathrm{case,} \mathrm{it} \mathrm{is} \mathrm{very} \mathrm{important}$ to investigate many different factors such as: fertilizing, pollinating, fruit-bearing, cropping, orchard longevity and others, even the economic basis for founding such plantations. An essential problem is to gain the knowledge about some cultivars propagated in Poland in terms of their usefulness for commercial fruit production. An answer to the first question is susceptibility to winter frost and late spring frost damage, independently of the fact that many authors have reported that Actinidia arguta and A. kolomikta are winter hardy enough (K r ü s s m a n n, 1976; D ir r, 1998). One of the primary problems in growing any of the Actinidia species is that the plants begin growing early in the spring and the young shoots and developing flower 
buds are extremely susceptible to injury from spring frosts. They can be damaged even by brief exposures to $-1^{\circ} \mathrm{C}$ degree or lower. Thus, flower buds are normally killed by spring freezes and the plants rarely produce fruit. Successful cropping of kiwi fruit may require a long frost-free growing season. Many cultivars are developed as a cross between other species or its cultivars and their frost hardiness in Poland is often unknown.

The first goal of this research was to evaluate growth habits and winter hardiness of eight cultivars of Actinidia arguta and A. kolomikta actually propagated by specialty nurseries and offered on the market. The second goal was to evaluate usefulness of these cultivars for orchards establishment.

\section{MATERIALS AND METHODS}

Plants of six cultivars of Actinidia arguta (Sieb. et Zucc.) Planch. ex Miq. (bower aktinidia) and two cultivars of A. kolomikta (Maxim. et Rupr.) Maxim. (kolomikta actinidia) purchased from a commercial nursery were planted outside (late spring 2005), in the field, at the Research Institute of Pomology and Floriculture in Skierniewice, central Poland, at a spacing of $3 \times 2.2 \mathrm{~m}$, on clay-sandy soil. From the cultivars of bower aktinidia, 'Geneva', 'Issai', 'Jumubo', 'Ken's Red', 'Weiki' (male), 'Weiki' (female), and kolomikta actinidia, 'Dr Szymanowski' and 'Sientiabrskaja', 3 plants were planted in 4 completely randomized blocks. The distribution of 'Weiki' male plants on the plots was supportive for flower pollination of typically female cultivars. The hermaphroditic cultivar 'Issai' is also a good pollinator for female flowers ( $\mathrm{R} \mathrm{e} \mathrm{i} \mathrm{c} \mathrm{h}$, 2004).

Plant height and number of shoots, frost damage of shoots and late spring frost damage of leaves were evaluated every year of the experiment. The results are presented as mean length and number of shoots. Evaluation of frost damage was conducted according to the following estimation values:

0 - plant not damaged

1 - shoots partly frozen, but buds developed well

2 - shoots frozen to the snow cover and new shoots developing at the base of plants

3 - whole plant killed by frost

Late spring frost damage was estimated and expressed in per cent:

$0 \%$ - plants not damaged and $100 \%$ - all new shoots and leaves on the plant completely devastated.

In February 2007, 10-cm long sections of oneyear-old shoots were taken from each cultivar for the lowest survival temperature test. Then, the shoots were placed on a growth dish covered with paper towel. The shoot sections were covered by small crystals of ice and placed in a fridge for 24-hour storage at a temperature of $-4^{\circ} \mathrm{C}$. After all the shoots were placed in the freezing chamber, Heraeus Vötsch (Austria), the temperature was dropped 2 degrees every two hours. In every temperature tested, $-24^{\circ} \mathrm{C},-26^{\circ} \mathrm{C},-28^{\circ} \mathrm{C}$, $-30^{\circ} \mathrm{C},-32^{\circ} \mathrm{C}$, and $-34^{\circ} \mathrm{C}$, the shoots were stored for 6 hours. Controlled freezing tests involved exposure of plants or plant parts to a decreasing temperature gradient. Sometimes, a single minimum temperature is used instead of graded temperature series. The extent of freeze-induced damage is assessed after low temperature treatment. A quantitative measure of cold hardiness can be derived on the basis of injury data. Comparable results are to be expected only after careful standardization of the whole testing procedure. Frost hardiness of actinidia cultivar shoots after crossing was assessed visually according to the survival test presented by Hołubowicz (1978), modified by $\mathrm{H} \mathrm{o} \mathrm{u} \mathrm{bow}$ i c z and B oj ar (1982), and after one week of storage of shoots at a temperature of $+22^{\circ} \mathrm{C}$. The degree of tissue damage is expressed by a fivedegree scale, where the value of one means that tissue is not damaged at all and five means the tissue is completely frozen. Four shoot sections from each plant for each temperature were taken. Signs of frost injury can be detected by visual examination of thawed tissue samples or intact plants. Usually, frost-injured tissues develop brown or yellowish colour due to oxidation of polyphenols (L i n d e n, 2002).

The experiment was set in randomized block design, and there were 4 replicates with 3 plants per replicate. The data were transformed as follows: $y=\operatorname{sqr}(x)$, and then analysed statistically with ANOVA, and they are presented as means for three years of the experiment (except for the freezing test). To determine the significance of differences between means, Duncan's multiple range test was used.

General climate conditions during the winter and early spring (December-April) in years 2006-2008.

Climate conditions during the winter months, December-April 2006, 2007 and 2008 were analyzed using the METHOS data system located $500 \mathrm{~m}$ away from the plots with actinidia plants. The 2005/06 winter had a very special course. The lowest mean day temperatures were noted on $22^{\text {nd }}$ and $24^{\text {th }}$ January, -22.6 ${ }^{\circ} \mathrm{C}$ and $-20.9^{\circ} \mathrm{C}$, respectively. The lowest air temperature during that winter in Skierniewice was observed during the night of 23th January, when the temperature dropped to $-28.8^{\circ} \mathrm{C}$. During that period of very strong frost, a snow cover of $24 \mathrm{~cm}$ was noted, under which the temperature was only $-6.5^{\circ} \mathrm{C}$. The $2006 / 07$ winter was completely different; the lowest mean day temperatures were noted in February (Fig. 1), during 


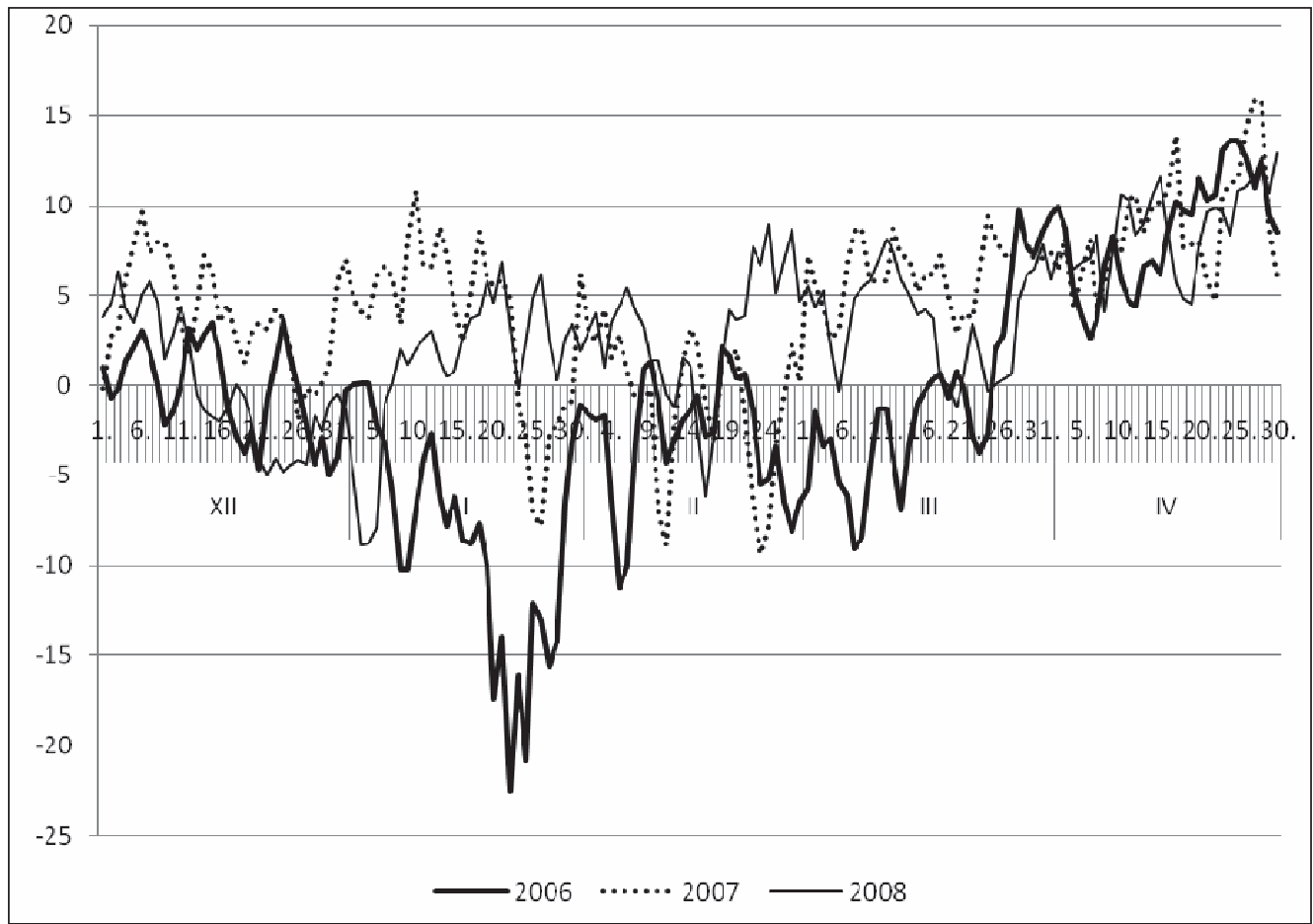

Fig. 1. Mean daily air temperature during winters 2005/06; 2006/07; 2007/08 in Skierniewice at 2 m height.

Table 1

Winter frost and early spring frost damage on Actinidia arguta and A. kolomikta cultivars.

\begin{tabular}{|c|c|c|c|c|c|c|}
\hline \multirow{2}{*}{ Cultivar } & \multicolumn{3}{|c|}{ Scale (from 0 to $3^{\circ}$ ) of winter frost damage } & \multicolumn{3}{|c|}{ Scale (from 0 to $100 \%$ ) of ground-frost damage } \\
\hline & 2006 & 2007 & 2008 & 2006 & 2007 & 2008 \\
\hline Dr. Szymanowski & $0.0 \mathrm{a}^{*}$ & - & - & - & $86.0 \mathrm{~b}$ & $0.0 \mathrm{a}$ \\
\hline Genewa & $1.0 \mathrm{ab}$ & - & - & - & $94.3 \mathrm{c}$ & $5.0 \mathrm{~b}$ \\
\hline Issai & $2.0 \mathrm{~b}$ & - & - & - & $98.4 \mathrm{~d}$ & $8.0 \mathrm{bc}$ \\
\hline Jumbo & $2.1 \mathrm{~b}$ & - & - & - & $96.6 \mathrm{~cd}$ & $7.5 b c$ \\
\hline Ken's Red & $2.0 \mathrm{~b}$ & - & - & - & $99.3 \mathrm{~d}$ & $10.3 \mathrm{c}$ \\
\hline Sientiabrskaja & $0.8 \mathrm{a}$ & - & - & - & $49.4 \mathrm{a}$ & $0.0 \mathrm{a}$ \\
\hline Weiki male & $1.9 \mathrm{~b}$ & - & - & - & $94.9 \mathrm{c}$ & $5.3 b$ \\
\hline Weiki female & $2.0 \mathrm{~b}$ & - & - & - & $87.5 b$ & $3.5 \mathrm{ab}$ \\
\hline
\end{tabular}

* Means followed by the same letter within the same year do not differ significantly according to Duncan's multiple test at $5 \%$ level of significance.

$0^{\circ}$ - plant not damaged; $1^{\circ}$ - shoots partly frozen, but buds are developed well; $2^{\circ}$ - shoots frozen to the snow cover and new shoots are developing at the base of plants; $3^{\circ}$ - whole plant killed by frost. 
that winter air temperature was above $0^{\circ} \mathrm{C}$ most of the time. Varying warmth was also observed in March and April with mean day temperatures above $5^{\circ} \mathrm{C}$. The first ground-frost was noted at the beginning of April with temperature $-2.5^{\circ} \mathrm{C}$, but the most dangerous groundfrost was noted on $22^{\text {nd }}-23^{\text {rd }}$ April when air temperature at the ground level dropped below $-5.3^{\circ} \mathrm{C}$, and the air temperature at that time was $-3.9^{\circ} \mathrm{C}$ (at $2 \mathrm{~m}$ height). The following 2007/08 winter was even warmer, but in the spring there were no such ground-frosts as those noted one year earlier (Fig. 1).

\section{RESULTS AND DISCUSSION}

\section{Evaluation of frost damage}

Strong frost damage on almost all the cultivars grown was noted after the 2005/06 winter, although the period of low temperatures lasted quite short, no longer than two days (Fig. 1). Five cultivars of $A$. arguta: 'Issai', 'Jumbo', 'Ken's Red', 'Weiki' male and 'Weiki' female, were completely frozen to the snow cover when temperature dropped to $-28.8^{\circ} \mathrm{C}$ (Tab. 1). However, according to D i r r's (1998) data, two of them, 'Genewa' and 'Issai', are listed as the most frost resistant ones, with the lowest survival temperature at $-33^{\circ} \mathrm{C}$. In the presented study, the cultivar 'Geneva' showed such resistance that only the tops of the shoots were frozen. Ge nits a ri at is et al. (1999) reported that frost resistance of kiwi plant buds gradually increases from autumn up to the middle of the winter, and at the end of the January resistance of leaves and flower buds of kiwi is the highest, and from that time up to the spring this resistance drops gradually. Hardy kiwi does not often survive the first growing season. This is generally due to planting in a poorly drained soil and development of root rot or neglecting after transplanting (G e n i t s a riat is et al. 1999). On the other hand, the ultimate survival of woody plants depends on not only on the maximal capacity of cold hardening, but also on the timing and rate of both cold acclimation and deacclimation, the stability of cold hardiness, and the ability to reacclimate after unseasonably warm periods (F u c h i g a mi et al. 1982). Good frost resistance against winter frost was shown by the cultivars of A. kolomikta, 'Dr Szymanowski and 'Sientiabrskaja', which were not damaged, and this was confirmed by data published previously (K r ü s s m a n n, 1976; D i r r, 1998). Young A. kolomikta plants (one-yearold) of the cultivar 'Lande' showed rather medium winter hardiness; other investigated cultivars wintered poorly. However, the two-year-old plants were sufficiently hardy (C h e s o n i e n e, 2000). Many times, the species Actinidia arguta, and A. kolomikta are used as a rootstock for fuzzy-skin cultivars, because of their higher frost resistance. Reciprocal grafting and budding between 'Hayward', Actinidia arguta, A.kolomikta, A.polygama, and A. deliciosa $x$ arguta hybrids was tested by $\mathrm{Ch}$ artier and $\mathrm{Blanchet}$ in 1997. The both way unions between 'Hayward' and A. arguta were short-lived. After eight years only a few 'Hayward' grafted onto A. kolomikta survived. The interspecific hybrids of $A$. deliciosa $x$ arguta were healthy as well as A.polygama onto 'Hayward'. But the frost damage experienced on the A. arguta rootstock under the actively growing 'Hayward' was disappointing ( $\mathrm{Ch}$ artier and B la n chet, 1997). During the following winters, in the presented study there was no frost damage on the tested plants, as the winters were warm and unusual for Polish climate.

The most dangerous for hardy kiwi plants are late spring frosts. The growth stage of the investigated cultivars continued for 186 days for A. kolomikta and 198 days for $A$. arguta. The earliest beginning of the growth season was observed in 2007 when budbreak for cultivars 'Issai', 'Jumbo' and 'Ken's Red' started on 11th March. In the spring of 2007, in central Poland the temperature at the ground level dropped from -5 to $-8^{\circ} \mathrm{C}$. For the cultivars of Actinidia arguta and A.kolomikta, such ground-frost caused very strong damage of young shoots, leaves and flower buds as well. Leaves and shoots of the A. arguta cultivars were almost completely frozen up to $10 \mathrm{~cm}$ long (Fig. 2). The severest damage of young leaves and shoots was noted on five cultivars of Actinidia arguta, from $94.3 \%$ of leaves damaged on 'Geneva' to $99.3 \%$ of leaves damaged on 'Ken's Red'. A little less damage was noted on the cultivar 'Weiki' female. Also the cultivar of A. kolomikta suffered less from ground-frost than the A. arguta cultivars. The plants of 'Dr Szymanowski' and 'Sientiabrskaja' were frozen in $86 \%$ and $49.4 \%$, respectively (Tab. 1). It is well known that Actinidia plants can be damaged by even brief exposure to $-1^{\circ} \mathrm{C}$ degree or lower (D irr, 1998; L a t o c ha, 2006). Thus, the flower buds are normally killed by spring freezes and the plants rarely produce fruit. Successful cropping of kiwifruit may require a long frost-free growing season. As it is shown in this experiment, resistance to severe ground-frost is dependent on species and cultivar. To sum up, effective hardening in winter can be achieved by a two-step acclimation of 1 -2 weeks, starting at a temperature of $0^{\circ}$ to $-3^{\circ} \mathrm{C}$, then dropping to $-5^{\circ}$ to $-10^{\circ} \mathrm{C}$. Proper dehardening can be attained by $1-3$ days exposure to temperatures above $+15^{\circ} \mathrm{C}$ in winter and above $+20^{\circ} \mathrm{C}$ in spring and autumn (S a kai and Larcher, 1987).

Freezing test of shoots of Actinidia cultivars

Controlled freezing tests showed and confirmed the data obtained by field culture that the cultivars of A. kolomikta are the most frost hardy among the tested 
Table 2

Frost hardiness of cv. Actinidia shoots after crossing; visual assessment according to the survival test presented by Hołubowicz and Bojar (1982).

\begin{tabular}{lcccccc}
\hline \multirow{2}{*}{ Cultivar } & \multicolumn{7}{c}{ Temperatures } \\
\cline { 2 - 7 } & $-24^{\circ} \mathrm{C}$ & $-26^{\circ} \mathrm{C}$ & $-28{ }^{\circ} \mathrm{C}$ & $-30^{\circ} \mathrm{C}$ & $-32^{\circ} \mathrm{C}$ & $-34^{\circ} \mathrm{C}$ \\
\hline Dr. Szymanowski & $0.0 \mathrm{a}$ & $0 \mathrm{a}$ & $0.0 \mathrm{a}$ & $0.0 \mathrm{a}$ & $0.3 \mathrm{a}$ & $0.8 \mathrm{a}$ \\
\hline Genewa & $0.0 \mathrm{a}$ & $0 \mathrm{a}$ & $0.6 \mathrm{~b}$ & $0.9 \mathrm{~b}$ & $1.6 \mathrm{~b}$ & $2.7 \mathrm{~b}$ \\
\hline Issai & $0.0 \mathrm{a}$ & $1.3 \mathrm{~b}$ & $1.9 \mathrm{c}$ & $2.3 \mathrm{c}$ & $2.9 \mathrm{c}$ & $3.8 \mathrm{c}$ \\
\hline Jumbo & $0.0 \mathrm{a}$ & $1.6 \mathrm{~b}$ & $2.3 \mathrm{c}$ & $3.1 \mathrm{~d}$ & $4.0 \mathrm{~d}$ & $5.0 \mathrm{~d}$ \\
\hline Ken's Red & $0.0 \mathrm{a}$ & $1.6 \mathrm{~b}$ & $2.0 \mathrm{c}$ & $2.7 \mathrm{~cd}$ & $3.9 \mathrm{~d}$ & $5.0 \mathrm{~d}$ \\
\hline Sientiabrskaja & $0.0 \mathrm{a}$ & $0 \mathrm{a}$ & $0.0 \mathrm{a}$ & $0.0 \mathrm{a}$ & $0.1 \mathrm{a}$ & $1.6 \mathrm{a}$ \\
\hline Weiki male & $0.0 \mathrm{a}$ & $1.2 \mathrm{~b}$ & $1.8 \mathrm{c}$ & $2.1 \mathrm{c}$ & $2.8 \mathrm{c}$ & $5.0 \mathrm{~b}$ \\
\hline Weiki female & $0.0 \mathrm{a}$ & $1.3 \mathrm{~b}$ & $1.8 \mathrm{c}$ & $2.0 \mathrm{c}$ & $2.9 \mathrm{c}$ & $5.0 \mathrm{~b}$ \\
\hline
\end{tabular}

* Means followed by the same letter within the same temperature do not differ significantly according to Duncan's multiple test at $5 \%$ level of significance.

Scale of survival test visual assessment $1^{\circ}-$ stem not damaged, no tissue discoloration, $2^{\circ}-$ slight tissue yellowing and browning, $3^{\circ}$ - moderate tissue browning $4^{\circ}$ - severe tissue browning, $5^{\circ}$ - stem completely frozen, tissue brown and black.

Table 3

Growth of Actinidia arguta and A. kolomikta cultivars after three years of culture.

\begin{tabular}{lcccccc}
\hline \multirow{2}{*}{ Cultivar } & \multicolumn{3}{c}{ Shoot length in cm /per year } & \multicolumn{2}{c}{ Number of shoot per plant / per year } \\
\cline { 2 - 7 } & 2006 & 2007 & 2008 & 2006 & 2007 & 2008 \\
\hline Dr. Szymanowski & $53,7 \mathrm{a} *$ & $46,2 \mathrm{a}$ & $48,3 \mathrm{a}$ & $3,2 \mathrm{a}$ & $3,8 \mathrm{a}$ & $4,2 \mathrm{a}$ \\
\hline Genewa & $127,4 \mathrm{~d}$ & $136,6 \mathrm{bc}$ & $174,5 \mathrm{~cd}$ & $4,0 \mathrm{ab}$ & $7,0 \mathrm{bc}$ & $10,3 \mathrm{bc}$ \\
\hline Issai & $63,5 \mathrm{a}$ & $43,2 \mathrm{a}$ & $79,6 \mathrm{~b}$ & $6,8 \mathrm{c}$ & $3,2 \mathrm{a}$ & $5,3 \mathrm{a}$ \\
\hline Jumbo & $115,8 \mathrm{~cd}$ & $142,5 \mathrm{c}$ & $219,5 \mathrm{~d}$ & $3,9 \mathrm{ab}$ & $8,8 \mathrm{c}$ & $13,6 \mathrm{c}$ \\
\hline Ken's Red & $89,9 \mathrm{~b}$ & $79,4 \mathrm{~b}$ & $93,6 \mathrm{~b}$ & $4,1 \mathrm{ab}$ & $6,6 \mathrm{bc}$ & $8,9 \mathrm{~b}$ \\
\hline Sientiabrskaja & $41,0 \mathrm{a}$ & $44,6 \mathrm{a}$ & $47,5 \mathrm{a}$ & $3,2 \mathrm{ab}$ & $3,2 \mathrm{a}$ & $4,4 \mathrm{a}$ \\
\hline Weiki male & $87,8 \mathrm{~b}$ & $84,4 \mathrm{~b}$ & $115,3 \mathrm{cb}$ & $5,7 \mathrm{bc}$ & $6,3 \mathrm{~b}$ & $9,1 \mathrm{~b}$ \\
\hline Weiki female & $101,0 \mathrm{bc}$ & $101,7 \mathrm{~b}$ & $132,6 \mathrm{c}$ & $4,3 \mathrm{ab}$ & $7,7 \mathrm{bc}$ & $10,8 \mathrm{bc}$ \\
\hline
\end{tabular}

\footnotetext{
* Means followed by the same letter within the same year do not differ significantly according to Duncan's multiple test at $5 \%$ level of significance.
} 
plants. As it is presented in Table 2, shoots of the cultivars 'Dr Szymanowski' and 'Sientiabrskaja' were only a little damaged at a temperature of $-36^{\circ} \mathrm{C}$ in comparison to the cultivars of A. arguta, 'Jumbo', 'Ken's Red', 'Weiki' male and 'Weiki' female, that were completely frozen. Serious damage, especially on 'Jumbo' and 'Ken's Red', took place at a temperature of $-30^{\circ} \mathrm{C}$ (Tab. 2). Slight tissue damage within a range of $1-2^{\circ}$ is easy to recover for plants, as confirmed by the work of Gonkiewicz (2008) on plum trees. The use of detached plant parts provides detailed information on the level of hardiness in different tissues and organs. The results have usually been in agreement with field observations of natural cold injury (L a p in s, 1962; Graham and Mullin, 1976; Pellet t et al. 1981). In the other experiment two-year-old Actinidia vines, grown on their own roots, were subjected to artificial freezing tests in midwinter to determine their relative hardiness. A. deliciosa var. deliciosa vines, which included the cultivars 'Abbott', 'Bruno', 'Greensill', 'Hayward' and 'Jones', were all severely damaged by exposure to a temperature of $-18 \mathrm{C}$ for 4 hours. Actindia arguta, A. kolomikta, and A. polygama appeared to be more tolerant to winter cold than $A$. deliciosa, indicating that potential germplasm exists for improvement of cold hardiness through interspecific hybridization (C h a t, 1995).

\section{Growth of actinidia}

In the second year of the experiment, severe ground-frost caused very strong growth reduction of the cultivated plants. The first growing shoots were almost completely damaged in late April, but except this the strongest growth was observed on A. arguta 'Genewa' and 'Jumbo'. Mean length of vegetative shoots after the first growing season was $127.4 \mathrm{~cm}$ and $115.8 \mathrm{~cm}$, respectively. Next year, it was 136.6 $\mathrm{cm}$ and $142.5 \mathrm{~cm}$, and in the following one 174.5 and 219.5, respectively (Tab. 3). The biggest number of shoots per plant was observed on 'Issai' and 'Weiki' male, mean shoot number was 6.8 and 5.7 per plant, respectively. However, in the following year good growth and a greater number of shoots were observed on 'Jumbo', 'Genewa', and 'Weiki' female. These data were confirmed by L a to ch a (2006) and R e i ch (2004), as the mentioned cultivars were classified by those authors as very strong growing climbers, requiring cutting of shoots in orchard culture in the summer and winter. In the presented study, such intervention was not necessary because during the first winter plants were damaged by frost, and during the second year, in April, by ground-frost. It is a very important fact that the cultivars 'Genewa' and 'Weiki' female in the third year of growth flowered abundantly and in the late summer first fruit setting was observed.
Flower buds of Actindia arguta and A. kolomikta were observed on flower shoots (short ones) and rarely on vegetative-flower shoots (long ones). However, fruit bearing was observed only on short flower shoots. Other cultivars in the experiment flowered and fruited less amply, and only 'Jumbo' in the experiment had flowers and fruits.

\section{CONCLUSION}

1. The cultivars of Actinidia kolomikta, 'Dr Szymanowski' and 'Sientiabrskaja', were the most winter hardy vines and the most ground-frost resistant. The growth of those plants was rather slow.

2. The cultivars of Actinidia arguta, 'Jumbo' and 'Genewa', were the strongest growing plants in the experiment. In the third year of the study, the greatest number of shoots and leaves was noted.

3. The cultivars of Actinidia arguta, 'Issai', 'Ken's Red', 'Weiki' male and 'Weiki' female, were moderate growing vines.

4. The least winterhardy of all the cultivars evaluated in the study are 'Jumbo' and 'Ken's Red' - A. arguta selections. However, the most important in the culture of these plants were late spring frosts that killed young shoots, leaves and flower buds.

\section{REFERENCES}

Chat J., 1995. Cold hardiness within the genus Actinidia. HortScience, 30: 186-193.

Chartier J., Bl a n chet P., 1997. Reciprocal grafting compatibility of kiwifruit and frost hardy actinidia species. Acta Horticulture, 444: 78-86.

Chesoniene L., 2000. Comparison of some bilogical features and potential of actinidia kolomikta cultivars. Acta Horticulture, 538.

Dir r M. A., 1998. Manual of woody landscape plants their identification, ornamental characteristics, culture, propagation and uses. Stipes Publishing, L. L. C., Illinois.

Fuchiga mi L. H., We is er, C. J., Kobay a shi K., Ti mmins R., Gusta L. V., 1982. A degree growth stage $\left({ }^{\circ} \mathrm{GS}\right)$ model and cold acclimation in temperate woody plants. [In:] P. H. Li and A. Sakai (eds), Plant cold hardiness and freezing stress, 2: 93-116, Academic Press. New York.

Genitsariatis M., Sfakiotakis E., Diamandid is D., 1999: Frost hardiness of kiwifruit buds in relation for seasonal changes of fatty acids. Acta Horticulture, 498: 179-184.

G on k iew ic z A., 2008. Evaluation of frost damage to shoots and flower buds of plum tres following the winter of 2005/06. Zeszyty Naukowe ISiK, 15: 29-34 (in polish).

Grah a m P. R., Mulli n R., 1976. A study of flower bud hardiness in azalea. Journal of the Amer. Soc. Hort. Sci. 101: 7-10. 
Hoł ubowicz T., 1978. Survival test as a method of frost injury estimation. Acta Horticulturae, 81: 119-122.

Hoł ub ow ic z T., B ojar K., 1982. Method of survival test. Material of seminar workshop group of Frosthardiness. Poznań: 52-56 (in Polish).

K r ü s s m a n n G., (1976): Handbuch der Laubgehölze. Band I. Paul Parey. Berlin und Hamburg.

Lapins K., 1962. Artificial freezing as a routine test of cold hardiness of young apple seedlings. Proceedings of the Amer. Soc. Hort. Sci. 81: 26-34.

L a t o ch a P., 2006. Actinidia - ornamental and useable plant. Hortpress. Warszawa (in Polish).

Linden L., 2002. Measuring cold hardiness in woody plants. Academic dissertation. FIN - 00014 University of Helsinki, Finland.

Pellett H., Carter J. V., 1981. Effect of nutritional factors on cold hardiness of plants. Horticultural Reviews, 3: 144-171.

Reich L., 2004. Uncommon fruits for every garden. Timber Press. 2004

S a ka i A., Larcher W., 1987. Frost survival of plants. Responses and adaptation to freezing stress. Ecological Studies, 62. Berlin, Springer Verlag: 321.

X i a o X., 1999. Progress in Actinidia selection and breeding in China. Acta Horticulture, 498: 25-36.

\section{Porównanie mrozoodporności i siły wzrostu odmian aktynidii ostrolistnej (Actinidia arguta) i pstrolistnej (A. kolomikta) uprawianych w centralnej Polsce}

\section{Streszczenie}

W Polsce odmiany aktynidii ostrolistnej i a. pstrolistnej należą do grupy silnie rosnących, ozdobnych pnączy przeznaczonych również jako rośliny użytkowe, ale głównie do uprawy amatorskiej. Owoce nazywane są potocznie mini kiwi. Właściwe owoce kiwi dostępne w sklepach należą do odmian aktynidii smakowitej (A. delicjosa) i aktynidii chińskiej (A. sinensis), która w Polsce wymarza podczas surowszych zim i nie owocuje. Aktynidie drobnoowocowe są mało znane, a jest realna możliwość wykorzystania ich również do większych nasadzeń towarowych. Celem niniejszej pracy było przedstawienie siły wzrostu i mrozoodporności 8 odmian należących do dwóch gatunków z rodzaju Actinidia. Silne uszkodzenia mrozowe niemal wszystkich uprawianych odmian odnotowano po zimie 2005/06. Mimo, iż okres ekstremalnie niskich temperatur trwał dość krótko, zaledwie trzy doby. W przypadku pięciu odmian aktynidii ostrolistnej jak Issai, Jumbo, Ken's Red, Weiki męska i Weiki żeńska zmarzły wszystkie pędy do granicy śniegu. Bardzo odporne na mróz okazały się odmiany aktynidii pstrolistnej: Dr. Szymanowski i Sientiabrskaja. Potwierdziły to także wyniki testu mrożeniowego w warunkach laboratoryjnych. Uszkodzenia mrozowe niektórych odmian pojawiały się już przy temperaturze $-26^{\circ} \mathrm{C}$. Dla odmian aktynidii najdotkliwsze okazały się przymrozki zanotowane w nocy z 21/22 kwietnia, które spowodowały silne uszkodzenia młodych liści i pędów. U większości odmian aktynidii ostrolistnej zniszczenia blaszek liściowych i pędów wynosiły od 94,3\% u odmiany Genewa do 99,3\% u odmiany Ken's Red. W mniejszym stopniu uszkodzona została odmiana Weiki żeńska (87,5\%), mniej ucierpiały także odmiany aktynidii pstrolistnej Dr Szymanowski (86\%) oraz Sientiabrskaja $(49,5 \%)$. 
